MEINBERG, Marcio Ortiz. Sobre a competência normativa do Conselho Monetário Nacional e do Banco Central do Brasil. Revista Eletrônica Direito e Política, Programa de Pós-Graduação Stricto Sensu em Ciência Jurídica da UNIVALI, Itajaí, v.16, n.3, $3^{\circ}$ quadrimestre de 2021. Disponível em: www.univali.br/direitoepolitica - ISSN 1980-7791.

\title{
SOBRE A COMPETÊNCIA NORMATIVA DO CONSELHO MONETÁRIO NACIONAL E DO BANCO CENTRAL DO BRASIL
}

\author{
ABOUT THE NORMATIVE POWERS OF THE CONSELHO MONETÁRIO NACIONAL \\ (NATIONAL MONETARY COUNCIL) AND THE BANCO CENTRAL DO BRASIL \\ (CENTRAL BANK OF BRAZIL)
}

Marcio Ortiz Meinberg ${ }^{1}$

\section{RESUMO:}

O objetivo deste artigo é atualizar o debate sobre a competência normativa do Conselho Monetário Nacional e do Banco Central do Brasil. Para tal, serão retomados aspectos históricos, resgatando a origem de tal competência e sua evolução jurídica ao longo do tempo. Além disso, serão abordados os principais debates doutrinários e jurisprudenciais relacionados à constitucionalidade da competência normativa após a promulgação da Constituição Federal de 1988. Por fim, serão apresentados alguns temas relacionados e que ainda podem gerar controvérsia, incluindo a Lei Complementar no 179/21. A metodologia adotada é a análise da bibliografia temática, da legislação e das decisões judiciais sobre o tema.

PALAVRAS-CHAVE: Lei Complementar no 179/21; ADCT; art. 25; Capacidade normativa de conjuntura; Sistema Financeiro Nacional (SFN); Separação dos Poderes.

\section{ABSTRACT}

The purpose of this article is to update the debate on the normative powers of the Conselho Monetário Nacional (National Monetary Council) and the Banco Central do Brasil (Central Bank of Brazil). To this end, historical aspects will be recovered, as well as the origin of such powers and its legal evolution over time. Moreover, will be addressed the main the main doctrinal and jurisprudential debates related to the constitutionality of the normative power after the promulgation of the Federal Constitution of 1988 . Finally, will be presented some related topics that

\footnotetext{
${ }^{1}$ Doutorando e Mestre em Direito Constitucional pela Pontifícia Universidade Católica de São Paulo (PUC-SP). Advogado em São Paulo-SP, Brasil. E-mail: marcio.meinberg@gmail.com.
} 
MEINBERG, Marcio Ortiz. Sobre a competência normativa do Conselho Monetário Nacional e do Banco Central do Brasil. Revista Eletrônica Direito e Política, Programa de Pós-Graduação Stricto Sensu em Ciência Jurídica da UNIVALI, Itajaí, v.16, n.3, $3^{\circ}$ quadrimestre de 2021. Disponível em: www.univali.br/direitoepolitica - ISSN 1980-7791.

may still generate controversy, including the Lei Complementar no 179/21 (Complementary Act no. 179/21).

KEYWORDS: Complementary Act no. 179/21; ADCT, art. 25; Normative capacity of conjuncture; Brazilian Financial System; Separation of Powers.

\section{INTRODUÇÃO}

O tema não é novo, mas merece ser retomado por conta da Lei Complementar no 179/21 (LC 179).

Desde sua criação em 1964, o Conselho Monetário Nacional (CMN) e o Banco Central do Brasil (BCB) exerceriam competência normativa dentro de suas atribuições. A partir da Constituição Federal de 1988 (CF88), a permanência de tal competência chegou a ser questionada, porém sua constitucionalidade tem sido reafirmada pelo Supremo Tribunal Federal (na ampla maioria das vezes, ainda que geralmente de forma lateral).

Apesar disso, após mais de três décadas, alguns aspectos relacionados ao tema ainda podem ser objeto de debate, incluindo o fato de ter sido aprovada a LC 179, que estabeleceu mudanças relevantes para um dos órgãos titulares da competência normativa (a chamada autonomia do BCB).

Iniciaremos este artigo fazendo um breve retrospecto legislativo sobre a competência normativa do $\mathrm{CMN}$ e do $\mathrm{BCB}$ e traçando alguns parâmetros conceituais. Em seguida, abordaremos a questão da constitucionalidade de tal competência normativa após a promulgação da CF88 e apresentando algumas posições doutrinárias (inclusive a nossa) e jurisprudenciais. Por fim, elencaremos e debateremos os alguns aspectos controversos sobre o tema que ainda não nos parecem ter sido satisfatoriamente solucionados, incluindo um tema contemporâneo decorrente da LC 179.

\section{LEI DE REFORMA BANCÁRIA (LEI No 4.595/64)}


MEINBERG, Marcio Ortiz. Sobre a competência normativa do Conselho Monetário Nacional e do Banco Central do Brasil. Revista Eletrônica Direito e Política, Programa de Pós-Graduação Stricto Sensu em Ciência Jurídica da UNIVALI, Itajaí, v.16, n.3, 30 quadrimestre de 2021. Disponível em: www.univali.br/direitoepolitica - ISSN 1980-7791.

O Sistema Financeiro Nacional (SFN) como o conhecemos foi estabelecido pela Reforma Bancária de 1964, por meio da Lei no 4.595/64². Tal reforma criou o CMN (a partir do conselho da Superintendência da Moeda e do Crédito - SUMOC) e o BCB (a partir do restante da estrutura da SUMOC), além de reestruturar todo o SFN.

Além disso, a Lei no 4.595/64 atribuiu competência normativa ao CMN (Lei no 4.595/64, art. $4^{\circ}$ ), ou seja, o poder de expedir normas inovadoras, inaugurais e obrigatórias $^{3}$. Diante disso, o CMN estaria legitimado a editar normas (inclusive gerais e abstratas) que inovem a ordem jurídica (sem serem leis), podendo estabelecer direitos e obrigações para seus destinatários.

Conforme ensina Fábio Konder Comparato ${ }^{4}$, o exercício da competência normativa pelo CMN seria o "preenchimento de uma norma legal em branco" constante na Lei no 4.595/64. Tratar-se-ia do fenômeno da "administrativização do Direito", necessário à regulação do Direito Econômico, uma vez que as leis não poderiam adaptar-se à veloz mutação das situações conjunturais, que também não poderiam (e nem deveriam) ser acompanhadas diuturnamente pelo Poder Legislativo ${ }^{5}$.

Haveria dois métodos para solucionar tal impasse ${ }^{6}$. Um deles seria o método francês, no qual são reservadas à lei "um certo número de matérias que dizem respeito aos princípios da organização política, social e econômica" e atribuindose "ao Poder Executivo a faculdade de disciplinar tudo o mais por meio de ordenações"7. Já o segundo método, seria o norte-americano, que "consiste na criação de órgãos executivos autônomos, aos quais a lei atribui poderes normativos específicos em setores determinados" ${ }^{\prime 8}$. No entendimento de

\footnotetext{
2 Aprovada na Ditadura Militar, ainda sob a Constituição de 1946.

3 ABRÃO, Nelson. Direito Bancário. 18 a ed. São Paulo: Saraiva Educação, 2019, p. 286.

4 COMPARATO, Fábio Konder. Abertura de crédito - Nulidade de cláusula contratual. In: Revista de Direito Mercantil, Industrial, Econômico e Financeiro, v. 10, n. 3, 1971, p.62-63.

5 COMPARATO, Fábio Konder. Abertura de crédito - Nulidade de cláusula contratual. p. 62.

6 COMPARATO, Fábio Konder. Abertura de crédito - Nulidade de cláusula contratual. p. 62.

7 COMPARATO, Fábio Konder. Abertura de crédito - Nulidade de cláusula contratual. p. 62.

8 COMPARATO, Fábio Konder. Abertura de crédito - Nulidade de cláusula contratual. p. 62-63
} 
MEINBERG, Marcio Ortiz. Sobre a competência normativa do Conselho Monetário Nacional e do Banco Central do Brasil. Revista Eletrônica Direito e Política, Programa de Pós-Graduação Stricto Sensu em Ciência Jurídica da UNIVALI, Itajaí, v.16, n.3, 30 quadrimestre de 2021. Disponível em: www.univali.br/direitoepolitica - ISSN 1980-7791.

Comparato", o segundo método teria sido "a trilha adotada pelo legislador brasileiro, durante o Estado Novo e também a partir de 1964".

Semelhante é o entendimento de Eros Roberto Grau ${ }^{10}$, para quem a lei pode atribuir aos órgãos da administração pública a denominada "capacidade normativa de conjuntura", ou seja, o poder-dever de "estatuir normas destinadas à regulação" das atividades dos particulares (decorrente do exercício de seu poder de polícia e fiscalização). A "capacidade normativa de conjuntura" é função normativa (produção de textos normativos jurídicos) o que não se confunde com a função legislativa (produzir leis formais) ${ }^{11}$. Tal capacidade normativa é apenas "conjuntural", limitada aos aspectos conjunturais que a motivaram e dentro dos estritos limites da lei que a atribuiu ${ }^{12}$.

Assim, em 1964, a lei teria criado o $C M N$ e o $B C B$ como órgãos executivos autônomos, aquele com poderes normativos específicos em seus setores de atuação. Desprende-se disso, então, o entendimento de que competência normativa não foi atribuída de forma ampla e ilimitada, para que o CMN regulamentasse quaisquer assuntos sem distinção. Ao contrário, o exercício deste poder é restrito às atividades relacionadas à política da moeda, do crédito e do câmbio, e à regulação das instituições financeiras (IFs), incluindo meios de pagamento $^{13}$.

Por fim, é importante fazer um esclarecimento: a competência normativa propriamente dita cabe do CMN, sendo que, na realidade, a Lei no 4.595/64 atribuiu ao BCB apenas a competência de cumprir e fazer cumprir as normas expedidas pelo CMN e, desta forma, complementar normas gerais e abstratas ${ }^{14}$, e

\footnotetext{
9 COMPARATO, Fábio Konder. Abertura de crédito - Nulidade de cláusula contratual. p. 62-63

$10 \mathrm{GRAU}$, Eros Roberto. O Direito Posto e o Direitos Pressuposto. São Paulo: Malheiros Editores, 2002, p. 231.

11 GRAU, Eros Roberto. O Direito Posto e o Direitos Pressuposto. p. 236 e 241.

12 GRAU, Eros Roberto. O Direito Posto e o Direitos Pressuposto. p. 232.

13 Vale observar que o CMN também possui competência normativa sobre outros temas, como o mercado de capitais e atividades das bolsas de valores e corretoras. Acontece que, como desde 1976 a supervisão destas atividades não cabe ao BCB, mas à Comissão de Valores Mobiliários (CVM), tais temas não interessam para o presente artigo.

14 SALOMÃO NETO, Eduardo. Direito Bancário. 3a ed. rev. e ampl. São Paulo: Trevisan Editora, 2020, p. 120 .
} 
MEINBERG, Marcio Ortiz. Sobre a competência normativa do Conselho Monetário Nacional e do Banco Central do Brasil. Revista Eletrônica Direito e Política, Programa de Pós-Graduação Stricto Sensu em Ciência Jurídica da UNIVALI, Itajaí, v.16, n.3, 30 quadrimestre de 2021. Disponível em: www.univali.br/direitoepolitica - ISSN 1980-7791.

dar publicidade às deliberações do CMN (entendimento de Eros Grau manifestado na ADI $2591^{15}$. Ou seja, a competência do BCB sempre foi subordinada e limitada ao que for estabelecido pelo $\mathrm{CMN}$, ou seja, meramente regulamentar (sem poder de inovar a ordem jurídica).

\section{CONSTITUIÇÃO FEDERAL DE 1988}

Com o fim da Ditadura Militar (em 1985) e a posterior promulgação da Constituição Federal de 1988, foi reestabelecido o Estado de Direito no Brasil. O novo regime é alicerçado na democracia (CF88, art. 10, "caput" e Parágrafo único, art. 60, §40, II), na forma federativa do Estado (CF88, art. 10, "caput", art. 60, §40, I), nos direitos e garantias fundamentais CF88, art. 50, art. 60, $4^{\circ}$, IV) e na separação dos Poderes (CF88, art. 20, art. 60, §40, III).

Consequentemente, resta assim analisar se, perante a nova Constituição, foi mantida a competência normativa do CMN.

\subsection{Separação dos Poderes}

O princípio da separação dos Poderes pressupõe a divisão das funções estatais (executiva, legislativa e jurisdicional) e a atribuição de cada uma delas a diferentes órgãos do Estado ${ }^{16}$ : os Poderes independentes e harmônicos entre si. Desta maneira, aos titulares do Poder Executivo (presidente, governadores e prefeitos)

\footnotetext{
15 BRASIL. Supremo Tribunal Federal. ADI 2591. Ação Direta de Inconstitucionalidade no 2.591-1/DF. Acórdão. Relator(a): CARLOS VELLOSO, Relator(a) p/ Acórdão: EROS GRAU, Tribunal Pleno, julgado em 07/06/2006, DJ 29/09/2006, p. 191. Disponível em $<$ https://redir.stf.jus.br/paginadorpub/paginador.jsp?docTP=AC\&docID=266855 $>$. Acesso em 24/07/2021.

${ }^{16}$ ARAÚJO, Luiz Alberto David; NUNES JÚNIOR, Vidal Serrano. Curso de Direito Constitucional. 22a ed. rev. e atual. São Paulo: Verbatim, 2018, p. 421-422.; FERRAZ, Anna Cândida da Cunha. Conflito entre Poderes. São Paulo: Editora Revista dos Tribunais, 1994, p. 17.; MORAES, Alexandre de. Direito Constitucional. 22a ed. São Paulo: Atlas, 2007, p. 393.; SILVA, José Afonso da. Curso de Direito Constitucional. 19a ed. rev. e atual. São Paulo: Malheiros, 2001, p. 113.
} 
MEINBERG, Marcio Ortiz. Sobre a competência normativa do Conselho Monetário Nacional e do Banco Central do Brasil. Revista Eletrônica Direito e Política, Programa de Pós-Graduação Stricto Sensu em Ciência Jurídica da UNIVALI, Itajaí, v.16, n.3, 30 quadrimestre de 2021. Disponível em: www.univali.br/direitoepolitica - ISSN 1980-7791.

caberia a função executiva: administrar a coisa pública dando cumprimento à lei ${ }^{17}$; aos titulares do Poder Judiciário (juízes e tribunais) caberia a função jurisdicional: aplicar o direito aos casos concretos para solucionar controvérsias ${ }^{18}$; e aos titulares do Poder Legislativo (Congresso Nacional, Assembleias Legislativas e Câmaras de Vereadores) caberia a função legislativa ${ }^{19}$ : criação e alteração do ordenamento jurídico ${ }^{20}$.

Ainda assim, contemporaneamente entende-se que o exercício de cada uma das funções pelo respectivo Poder não é exclusivo, de modo que cada Poder exerce prioritariamente sua função típica, mas também exerce atipicamente as duas demais funções ${ }^{21}$. Isso, posto, o Poder Legislativo, além de legislar (sua função típica), também exerce a função executiva quando exerce atos administrativos (ex. licitações próprias, provimento de seus servidores etc.) e exerce a função jurisdicional quando realiza julgamentos (sejam julgamentos internos, como externos, no caso do "impeachment") 22 . Da mesma forma, então, a função legislativa também é exercida atipicamente pelos Poderes Executivo (que expede regulamentos, edita medidas provisórias e elabora leis delegadas) e Judiciário (que elabora seus regimentos internos) $)^{23}$.

\subsection{Princípio da legalidade}

Em particular, com relação ao exercício da função legislativa, existe um outro aspecto absolutamente fundamental que é o chamado princípio da legalidade

\footnotetext{
17 ARAÚJO, Luiz Alberto David; NUNES JÚNIOR, Vidal Serrano. Curso de Direito Constitucional. p. 421.

18 SILVA, José Afonso da. Curso de Direito Constitucional. p. 112.

19 Parte da doutrina também identifica, como função típica do Poder Legislativo, a função fiscalizatória, cf. ARAÚjO, Luiz Alberto David; NUNES JÚNIOR, Vidal Serrano. Curso de Direito Constitucional. p. 499.; e MORAES, Alexandre de. Direito Constitucional. p. 399.

20 ARAÚJO, Luiz Alberto David; NUNES JÚNIOR, Vidal Serrano. Curso de Direito Constitucional. p. 421.

${ }^{21}$ ARAÚJO, Luiz Alberto David; NUNES JÚNIOR, Vidal Serrano. Curso de Direito Constitucional. p. 425.; MORAES, Alexandre de. Direito Constitucional. p. 399.

22 MELLO, Celso Antônio Bandeira de. Curso de Direito Administrativo. 26a ed. rev. e atual. São Paulo, Malheiros, 2009, p. 33.

${ }^{23}$ MELLO, Celso Antônio Bandeira de. Curso de Direito Administrativo. p. 34.
} 
MEINBERG, Marcio Ortiz. Sobre a competência normativa do Conselho Monetário Nacional e do Banco Central do Brasil. Revista Eletrônica Direito e Política, Programa de Pós-Graduação Stricto Sensu em Ciência Jurídica da UNIVALI, Itajaí, v.16, n.3, 30 quadrimestre de 2021. Disponível em: www.univali.br/direitoepolitica - ISSN 1980-7791.

(CF88, art. 50, II), que estabelece que "ninguém será obrigado a fazer ou deixar de fazer alguma coisa senão em virtude de lei". Se considerarmos que só existem três modais deônticos (obrigação, proibição e permissão), o princípio da legalidade significa que as obrigações e proibições somente podem ser instituídos por lei, e, na ausência da lei, restará sempre a permissão ${ }^{24}$.

O papel elevado reservado à lei decorre do fato de que ela é a formalização da vontade geral, materializada de acordo com um processo legislativo que envolve a participação dos órgãos de representação popular (Legislativo e Executivo) ${ }^{25}$.

Note que a expressão "em virtude de lei" constante no artigo 50, inciso II, da Constituição, também pode contemplar os atos equiparados a lei, como medidas provisórias e leis delegadas ${ }^{26}$, exceto onde haja referência constitucional explícita para a reserva legal, quando somente a lei formal será admitida, como em alguns casos de matéria tributária e penal ${ }^{27}$. O princípio da legalidade, no entanto, não admite a inovação da ordem jurídica (criação, modificação ou extinção de direitos e obrigações) por espécies normativas inferiores à $l \mathrm{li}^{28}$, como regulamentos, decretos, resoluções, circulares, portarias etc.

Neste sentido, ensina Celso Antônio Bandeira de Mello:

Nos termos do art. 50, II, "ninguém será obrigado a fazer ou deixar de fazer alguma coisa senão em virtude de lei". Aí não se fiz "em virtude de" decreto, regulamento, resolução, portaria ou quejandos. Diz-se "em virtude de lei". Logo a Administração não pode proibir ou impor comportamento algum a terceiros, salvo se estiver previamente embasada em determinada lei que Ihe faculte proibir ou impor algo a quem quer que seja. Vale dizer, não lhe é possível expedir regulamentos instrução, resolução, portaria ou seja lá que ato for para coartar a liberdade dos administrados, salvo se em

${ }^{24}$ ARAÚJO, Luiz Alberto David; NUNES JÚNIOR, Vidal Serrano. Curso de Direito Constitucional. p. 209.

25 SILVA, José Afonso da. Curso de Direito Constitucional. p. 423.

26 SILVA, José Afonso da. Curso de Direito Constitucional. p. 424.

27 SILVA, José Afonso da. Curso de Direito Constitucional. p. 431-432.

28 SILVA, José Afonso da. Curso de Direito Constitucional. p. 429. 
MEINBERG, Marcio Ortiz. Sobre a competência normativa do Conselho Monetário Nacional e do Banco Central do Brasil. Revista Eletrônica Direito e Política, Programa de Pós-Graduação Stricto Sensu em Ciência Jurídica da UNIVALI, Itajaí, v.16, n.3, 30 quadrimestre de 2021. Disponível em: www.univali.br/direitoepolitica - ISSN 1980-7791.

lei já existir delineada a contenção ou imposição que o ato administrativo venha a minudenciar. ${ }^{29}$

Em resumo, as normas infraconstitucionais podem "minudenciar" as disposições das leis (nas quais devem estar previstos os "elementos essenciais da providência impositiva"30), sem nunca ampliar, modificar ou inovar seu conteúdo.

\subsection{ADCT, artigo 25}

Enfim, além dos aspectos já citados (separação dos Poderes e princípio da legalidade) o tema possui um terceiro complicador que é o artigo 25 do Ato das Disposições Constitucionais Transitórias (ADCT).

As disposições transitórias são dispositivos jurídicos passageiros que cuidam da "transição de um sistema legal preestabelecido e aquele determinado por um novo ato da ordem jurídica"31. Como o próprio termo indica, as disposições transitórias são passageiras e tendem a desaparecer com o tempo ${ }^{32}$. No caso da Constituição, são as normas necessárias para realizar a transição da ordem constitucional anterior para a nova (uma vez que ambas não podem conviver) e regulamentar a recepção do ordenamento jurídico, que não desaparece sumariamente com a promulgação da nova Constituição ${ }^{33}$.

Em particular, no Ato das Disposições Constitucionais Transitórias da Constituição de 1988 foi previsto o seguinte:

Art. 25. Ficam revogados, a partir de cento e oitenta dias da promulgação da Constituição, sujeito este prazo a prorrogação por lei, todos os dispositivos legais que atribuam ou deleguem a órgão do Poder Executivo competência

\footnotetext{
29 MELLO, Celso Antônio Bandeira de. Curso de Direito Administrativo. p. 102-103.

30 SILVA, José Afonso da. Curso de Direito Constitucional. p. 424.

31 PINHEIRO, Hélio Fernandes. apud PESSOA, João Paulo. As Disposições Transitórias do Direito Constitucional Brasileiro. Rio de Janeiro: Lumen Juris, 2017, p.49

32 PESSOA, João Paulo. As Disposições Transitórias do Direito Constitucional Brasileiro. p. 49-50.

33 PESSOA, João Paulo. As Disposições Transitórias do Direito Constitucional Brasileiro. p. 77.
} 
MEINBERG, Marcio Ortiz. Sobre a competência normativa do Conselho Monetário Nacional e do Banco Central do Brasil. Revista Eletrônica Direito e Política, Programa de Pós-Graduação Stricto Sensu em Ciência Jurídica da UNIVALI, Itajaí, v.16, n.3, $3^{\circ}$ quadrimestre de 2021. Disponível em: www.univali.br/direitoepolitica - ISSN 1980-7791.

assinalada pela Constituição ao Congresso Nacional, especialmente no que tange a:

I - ação normativa;

Como se vê, trata-se do reconhecimento de que, para a Constituição de 1988, a competência normativa cabe exclusivamente ao Congresso Nacional. Não obstante, o constituinte estabeleceu uma regra de transição, pela qual haveria um prazo de 180 antes que fosse revogada a competência normativa anteriormente atribuída aos órgãos do Poder Executivo (na qual se inclui o CMN).

Ocorre que o próprio artigo 25 do ADCT previu a possibilidade de que este prazo fosse prorrogado por lei. Foi o que efetivamente aconteceu.

Em 31/03/1989 (dois dias antes do prazo original assinalado pelo ADCT, art. 25), foi publicada a Medida Provisória no 45/89 que prorrogou até 30/04/1990 (treze meses) as competências normativas do CMN, Conselho Nacional do Comércio Exterior, Conselho Nacional de Seguros Privados e Conselho Interministerial de Preços. A MP 45/89 não foi convertida em lei e, em 05/05/1989 (cinco dias após expirar), foi "reeditada" pela MP 53/89, com redação similar, mas prorrogando as competências normativas até 30/10/1989 (seis meses). A MP 53/89 foi convertida na Lei no 7.770/89.

Em 25/10/1989 (cinco dias antes do prazo), foi publicada a MP 100/89, que previa a prorrogação do prazo indicado na Lei no 7.770/89 "até a data da promulgação da Lei Complementar de que trata o art. 192 da Constituição" (prazo indeterminado). Em 24/11/1989, a MP 100/89 foi convertida na Lei no 7.892/89, que retomou a fórmula original, mas estabeleceu a prorrogação de prazo de vigência das competências normativas do CMN (e demais órgãos indicados na Lei no $7.770 / 89$ ) até $31 / 05 / 1990$ (seis meses).

Em 31/05/1990 (no último dia do prazo), foi publicada a MP 188/90, prorrogando o prazo de vigência das competências normativas do CMN e do Conselho Nacional de Seguros Privados (somente estes órgãos) até 31/12/1990 (sete meses), e alterando a composição do CMN. Em 28/06/1990, a MP 188/90 foi convertida na Lei no 8.056/90. 
MEINBERG, Marcio Ortiz. Sobre a competência normativa do Conselho Monetário Nacional e do Banco Central do Brasil. Revista Eletrônica Direito e Política, Programa de Pós-Graduação Stricto Sensu em Ciência Jurídica da UNIVALI, Itajaí, v.16, n.3, $3^{\circ}$ quadrimestre de 2021. Disponível em: www.univali.br/direitoepolitica - ISSN 1980-7791.

Em 11/12/1990 (20 dias antes do prazo), foi publicada a MP 277/90, prorrogando o prazo da Lei no 8.056/90 até 30/06/1991 (pouco mais de seis meses). Em 20/12/1990, a MP 277/90 foi convertida na Lei no 8.127/90.

Em 10/07/1991 (um dia após o prazo), foi publicada a Lei no 8.201/91, prorrogando o prazo de vigência das competências normativas do CMN e do Conselho Nacional de Seguros Privados até 31/12/1991 (seis meses).

Em 31/12/1991 (no último dia do prazo), foi publicada a Lei no 8.392/91, prorrogando o prazo de vigência das competências normativas do CMN e do Conselho Nacional de Seguros Privados "até a data da promulgação da lei complementar de que trata o art. 192 da Constituição Federal" (prazo indeterminado, retomando a fórmula da MP 100/89). Posteriormente a redação da Lei no 8.392/91 foi alterada pela Lei no 9.069/91 (Lei do Plano Real), removendo a competência normativa do CMN sobre a emissão de papel-moeda e alterando a composição e estrutura do CMN.

Em suma, com fundamento no artigo 25 do ADCT, por sucessivas medidas provisórias e leis, a competência normativa do CMN tem sido mantida em vigor, aguardando a promulgação da lei complementar prevista no artigo 192, da Constituição Federal (que estruturaria o Sistema Financeiro Nacional). Vale recordar, contudo, que em 2003 (20 anos após a Lei no 8.392/91), a Emenda Constitucional no 40/03 deu nova redação ao referido artigo 192, da Constituição, que passou a prever expressamente que o Sistema Financeiro Nacional seria regulado por leis complementares (no plural).

\section{POSIÇÕES DOUTRINÁRIAS}

Após a promulgação da Constituição Federal de 1988, a competência normativa do CMN passou a ser objeto de questionamentos, especialmente por conta da separação dos Poderes, princípio da legalidade e do artigo 25 do ADCT. 
MEINBERG, Marcio Ortiz. Sobre a competência normativa do Conselho Monetário Nacional e do Banco Central do Brasil. Revista Eletrônica Direito e Política, Programa de Pós-Graduação Stricto Sensu em Ciência Jurídica da UNIVALI, Itajaí, v.16, n.3, 30 quadrimestre de 2021. Disponível em: www.univali.br/direitoepolitica - ISSN 1980-7791.

A doutrina se dividiu quanto à constitucionalidade da competência normativa do CMN. É interessante observar como o tema opôs ilustres administrativistas (Geraldo Ataliba e Celso Antônio Bandeira de Mello, que entendem ser inconstitucional) aos grandes estudiosos do Direito Bancário (Nelson Abrão e Eduardo Salomão Neto, que defendem a constitucionalidade).

\subsection{Pela inconstitucionalidade}

Iniciaremos pela primeira posição, ou seja, pela inconstitucionalidade da competência normativa do CMN.

Segundo Ataliba ${ }^{34}$, caberia apenas ao Congresso Nacional o poder-dever de legislar, não podendo este nem se exonerar (direta ou indiretamente) e nem delegar tal função (exceto se houver previsão constitucional autorizando). Isso posto, o CMN somente poderia dar execução à lei, sendo que somente esta poderia estabelecer obrigações e deveres ${ }^{35}$.

Para Ataliba ${ }^{36}$, ante o princípio da legalidade, até mesmo a capacidade normativaregulamentar teria sido atribuída exclusivamente "ao Presidente da República (CF88, art. 84, IV, 2a parte) e aos Ministros de Estado (CF88, art. 87, II), com exclusão de todo e qualquer outro órgão". Dessarte, a única coisa que "a lei pode fazer é prever competências infra-regulamentares para CMN, Conselho de Trânsito, de Educação etc." 37. Tais competências infra-regulamentares (nos estritos limites da lei) não incluiriam a expedição de normas inovadoras, inaugurais e obrigatórias ${ }^{38}$.

34 ATALIBA, Geraldo. Delegação Normativa (Limites às Competências do C.M.N. e BACEN). In: Revista de Informação Legislativa, Brasília, a. 29, n. 113, p. 275- 306, jan/mar, 1992, p. 289. Disponível <https://www2.senado.leg.br/bdsf/bitstream/handle/id/175926/000459246.pdf?sequence=1\&isAll owed $=y>$. Acesso em 24/07/2021.

35 ATALIBA, Geraldo. Delegação Normativa (Limites às Competências do C.M.N. e BACEN). p. 282.

36 ATALIBA, Geraldo. Delegação Normativa (Limites às Competências do C.M.N. e BACEN). p. 291.

37 ATALIBA, Geraldo. Delegação Normativa (Limites às Competências do C.M.N. e BACEN). p. 291.

38 ATALIBA, Geraldo. Delegação Normativa (Limites às Competências do C.M.N. e BACEN). p. 293. 
MEINBERG, Marcio Ortiz. Sobre a competência normativa do Conselho Monetário Nacional e do Banco Central do Brasil. Revista Eletrônica Direito e Política, Programa de Pós-Graduação Stricto Sensu em Ciência Jurídica da UNIVALI, Itajaí, v.16, n.3, 30 quadrimestre de 2021. Disponível em: www.univali.br/direitoepolitica - ISSN 1980-7791.

Com relação ao artigo 25 do Ato das Disposições Transitórias, Ataliba ${ }^{39}$ argumenta que, ainda que fosse possível a prorrogação da vigência da competência normativa do CMN, esta deveria ter ocorrido por lei formal até o prazo máximo de 05/04/1989. Segundo Ataliba40, a prorrogação por lei não seria válida ("medida provisória não é lei"), ainda mais se considerar que a referida MP 45/89 não foi convertida em lei. Deste modo, como não houve lei formal antes de 05/04/1989, a competência normativa do CMN teria perdido definitivamente sua fundamentação, não sendo possível que leis posteriores prorrogassem a norma que já não mais integrava o sistema ${ }^{41}$.

Por fim, acrescentamos o pensamento de Celso Antônio Bandeira de Mello, para quem "a prorrogação por lei não pode ser admitida para sempre" ${ }^{42}$, ou seja, ainda que se admitisse a validade da MP 45/89, está não poderia ser novamente prorrogada após 5/04/198943. Caso contrário, estaríamos admitindo a possibilidade de prorrogações sem limites de disposições que a própria Constituição Federal de 1988 não admite, exceto transitoriamente (o que não pode ser indefinidamente). Nesta perspectiva, Celso Antônio Bandeira de Mello:

Prorrogação sem limite (para manter exceções à Constituição) seria incompatível com a natureza das próprias "disposições transitórias". Com maior razão, inaplicável, incabível numa simples lei. ${ }^{44}$

E mais além:

A prorrogação por lei não pode ser admitida para sempre. Sem Prazo. É inadmissível disposição transitória que abrigue interpretação permitindo que medidas infra-constitucionais contrariando a Constituição persistam indefinidamente. ${ }^{45}$

\footnotetext{
39 ATALIBA, Geraldo. Delegação Normativa (Limites às Competências do C.M.N. e BACEN). p. 294.

40 ATALIBA, Geraldo. Delegação Normativa (Limites às Competências do C.M.N. e BACEN). p. 297.

41 ATALIBA, Geraldo. Delegação Normativa (Limites às Competências do C.M.N. e BACEN). p. 295.

42 MELLO, Celso Antônio Bandeira de. apud ATALIBA, Geraldo. Delegação Normativa (Limites às Competências do C.M.N. e BACEN). p. 297.

43 ATALIBA, Geraldo. Delegação Normativa (Limites às Competências do C.M.N. e BACEN). p. 297.

44 MELLO, Celso Antônio Bandeira de. apud ATALIBA, Geraldo. Delegação Normativa (Limites às Competências do C.M.N. e BACEN). p. 296.

45 MELLO, Celso Antônio Bandeira de. apud ATALIBA, Geraldo. Delegação Normativa (Limites às Competências do C.M.N. e BACEN). p. 297.
} 
MEINBERG, Marcio Ortiz. Sobre a competência normativa do Conselho Monetário Nacional e do Banco Central do Brasil. Revista Eletrônica Direito e Política, Programa de Pós-Graduação Stricto Sensu em Ciência Jurídica da UNIVALI, Itajaí, v.16, n.3, $3^{\circ}$ quadrimestre de 2021. Disponível em: www.univali.br/direitoepolitica - ISSN 1980-7791.

Enfim todo o raciocínio dos administrativistas confluiu para o artigo 25 do ADCT, reconhecendo (ao menos temporariamente) a possibilidade de prorrogação da competência normativa do CMN por meio de lei. Com relação à situação concreta, a eventual inconstitucionalidade viria de problemas formais (como a prorrogação inicial via medida provisória não convertida em lei) e do fato de que a prorrogação sem limites de prazo seria incompatível com o caráter transitório do ADCT.

Antes de apresentar a posição do Supremo Tribunal Federal, abordaremos também a argumentação dos doutrinadores que defendem a constitucionalidade da competência normativa do CMN.

\subsection{Pela constitucionalidade}

Passemos agora a abordar a segunda posição, que reconhece a constitucionalidade da competência normativa do CMN sob a Constituição de 1988.

No entendimento de Nelson Abrão ${ }^{46}$, o Direito Econômico depende de uma técnica legislativa diferenciada, pois a via econômica e financeira possui extraordinária velocidade, que não é satisfatoriamente acompanhada pelo Poder Legislativo, sendo necessária "a edição de leis menores, de elaboração mais rápida e menos complexa". Diante disso, Abrão conclui, amparado em Fábio Konder Comparato, que a Lei no 4.595/64 instituiu "normas em branco", atribuindo poderes normativos para alguns órgãos executivos autônomos, entre os quais o CMN e o $\mathrm{BCB}^{47}$.

Contudo, faltou a Abrão (e aos continuadores de sua obra) atualizar esta questão sob os auspícios da Constituição de 1988. Afinal, na atual Constituição não se localiza qualquer dispositivo que fundamente a existência de órgãos autônomos com poderes normativos específicos, mas muito pelo contrário. Aquele entendimento, se coerente com os regimes do Estado Novo ou da Ditadura Militar

46 ABRÃO, Nelson. Direito Bancário. p. 285.

${ }^{47}$ COMPARATO, Fábio Konder. apud ABRÃO, Nelson. Direito Bancário. p. 287-288. 
MEINBERG, Marcio Ortiz. Sobre a competência normativa do Conselho Monetário Nacional e do Banco Central do Brasil. Revista Eletrônica Direito e Política, Programa de Pós-Graduação Stricto Sensu em Ciência Jurídica da UNIVALI, Itajaí, v.16, n.3, 30 quadrimestre de 2021. Disponível em: www.univali.br/direitoepolitica - ISSN 1980-7791.

(referenciados diretamente pelo próprio Comparato ${ }^{48}$, não mais se sustenta diante da atual Constituição, que prima pela separação dos Poderes e pelo princípio da Legalidade. À vista disso, a competência normativa do CMN só pode ser compreendida como um resquício do regime anterior, mas, infelizmente, Abrão não enfrenta a questão do artigo 25 do $A D C T$, que nos parece a mais central para a conclusão desta contenda.

Por sua vez, Eduardo Salomão Neto ${ }^{49}$ debate o tema sob dois prismas, o econômico e o jurídico. Com relação ao prisma jurídico, argumenta que, para o Direito Econômico, a legislação comum é um procedimento decisório mais lento do que a regulação administrativa ${ }^{50}$. Por outro lado, a regulação administrativa implica em custo maior, pois depende de um órgão especializado, devidamente estruturado para a tarefa ${ }^{51}$.

Sob o prisma jurídico, Salomão Neto ${ }^{52}$ inicialmente rebate o entendimento de que a separação dos Poderes implicaria na exclusividade do Poder Legislativo para emitir normas, uma vez que o Poder Executivo também participa do processo legislativo (veto, iniciativa de lei, sanção, promulgação e publicação das leis), bem como pode editar medidas provisórias e elaborar leis delegadas.

Com relação à competência normativa do $\mathrm{CMN}$ e do $\mathrm{BCB}$, Salomão Neto $^{53}$ contrapõe a posição de Celso Antônio Bandeira de Mello (para quem "os regulamentos não podem aportar à ordem jurídica direito ou obrigação que já não estejam, na lei, previamente caracterizados e de modo suficiente" ${ }^{24}$ ) ao entendimento de Eros Roberto Grau. Segundo Grau ${ }^{55}$, a função legislativa (capacidade do Poder Legislativo produzir leis) não se confunde com a função normativa (estabelecer preceito abstrato, genérico e inovador, ainda que sem

\footnotetext{
48 COMPARATO, Fábio Konder. Abertura de crédito - Nulidade de cláusula contratual. p. 62.

49 SALOMÃO NETO, Eduardo. Direito Bancário. p. 120-136

50 SALOMÃO NETO, Eduardo. Direito Bancário. p. 121.

51 SALOMÃO NETO, Eduardo. Direito Bancário. p. 122-123.

52 SALOMÃO NETO, Eduardo. Direito Bancário. p. 132.

53 SALOMÃO NETO, Eduardo. Direito Bancário. p. 125.

54 MELLO, Celso Antonio Bandeira de. apud SALOMÃO NETO, Eduardo. Direito Bancário. p. 125.

55 GRAU, Eros Roberto. apud SALOMÃO NETO, Eduardo. Direito Bancário. p. 126.
} 
MEINBERG, Marcio Ortiz. Sobre a competência normativa do Conselho Monetário Nacional e do Banco Central do Brasil. Revista Eletrônica Direito e Política, Programa de Pós-Graduação Stricto Sensu em Ciência Jurídica da UNIVALI, Itajaí, v.16, n.3, 30 quadrimestre de 2021. Disponível em: www.univali.br/direitoepolitica - ISSN 1980-7791.

forma de lei), sendo que a função normativa é distribuída por todo o Estado, bastando que haja autorização por lei (ou seja, o a competência normativa seria de uma função originária do Executivo e não uma delegação do Poder Legislativo). Nesta acepção, a expressão "em virtude de lei" constante no artigo 50, II, da Constituição, exigiria apenas que a norma possua um fundamento de validade na lei, sem necessidade de possuir forma de lei (exceto quando a Constituição expressamente o determinar, como nos casos de matéria penal e tributária já citados anteriormente) ${ }^{56}$. Por fim, conclui que competência normativa do CMN e do BCB seria materializada por meio de "regulamentos autorizados" 57 , válidos com fundamento na Lei no $4.595 / 64^{58}$.

Salomão Neto ${ }^{59}$ complementa a elaboração, acrescentando que não basta à lei apenas autorizar o exercício da competência normativa, sendo necessário também que esta fixe os valores a serem concretizados. No caso da competência normativa do $C M N$ e do $B C B$, os valores foram previstos nos artigos $2^{\circ}$ e $3^{\circ}$, da Lei no 4.595/64, ou seja, objetivar o "o progresso econômico e social do País" naqueles termos ${ }^{60}$.

Enfim, Salomão Neto ${ }^{61}$ aborda a questão do artigo 25 do Ato das Disposições Constitucionais Transitórias, reconhecendo a existência de "alguns tropeços" neste "verdadeiro emaranhado de normativos" (como a publicação de leis e MPs após o decurso do prazo das anteriores, ou o fato de que o BCB sequer é mencionado nos normativos). Mesmo assim, segundo Salomão Neto ${ }^{62}$, a competência normativa do $C M N$ e do BCB não seria prejudicada, pois não estaria enquadrada na hipótese do art. 25 do ADCT, visto que seu fundamento é outro (já explicitado anteriormente).

\footnotetext{
56 SALOMÃO NETO, Eduardo. Direito Bancário. p. 126.

57 Para Eros Grau (apud SALOMÃO NETO, Eduardo. Direito Bancário. p. 27), existem três tipos de regulamento: (i) os regulamentos de execução de lei (CF, art. 84, IV); (ii) os regulamentos autorizados, destinados ao exercício da função normativa pelo Executivo, mediante autorização legislativa explícita; e (iii) os regulamentos autônomos, decorrentes da atribuição de função normativa implícita pela Constituição ao Executivo.

58 SALOMÃO NETO, Eduardo. Direito Bancário. p. 127.

59 SALOMÃO NETO, Eduardo. Direito Bancário. p. 127.

60 SALOMÃO NETO, Eduardo. Direito Bancário. p. 128.

61 SALOMÃO NETO, Eduardo. Direito Bancário. p. 128.

62 SALOMÃO NETO, Eduardo. Direito Bancário. p. 128.
} 
MEINBERG, Marcio Ortiz. Sobre a competência normativa do Conselho Monetário Nacional e do Banco Central do Brasil. Revista Eletrônica Direito e Política, Programa de Pós-Graduação Stricto Sensu em Ciência Jurídica da UNIVALI, Itajaí, v.16, n.3, $3^{\circ}$ quadrimestre de 2021. Disponível em: www.univali.br/direitoepolitica - ISSN 1980-7791.

Para Salomão Neto63, o artigo 25 do ADCT teria apenas "por finalidade manter vigentes as competências normativas gerais atribuídas pelo antigo regime ao Poder Executivo até que o Estado estivesse apto a exercê-las nos termos da nova Constituição Federal", o que seria diferente dos "regulamentos autorizados" (que incluem a competência normativa do CMN e do BCB).

Ainda que o raciocínio de Grau e Salomão Neto seja fundamentado e elegante, também não localizamos qualquer dispositivo constitucional que justifique a existência de regulamentos autorizados ou autônomos, com poder normativo oponível a terceiros. Além disso, o princípio da legalidade e da separação dos Poderes perderiam seu sentido se fosse possível redistribuir as competências constitucionais mediante lei ordinária (tratar-se-ia de uma visão apenas formal da Constituição, o que é totalmente incompatível com sua ampla carta de princípios). Novamente, tal entendimento somente teria lugar sob o regime anterior ao inaugurado pela Constituição de 1988 e, após isso, como resquício fundamentado no artigo 25 do ADCT (que o próprio Salomão Neto ${ }^{64}$, vê o tema como prejudicado, devido a "alguns tropeços que teriam por certo tirado a vigência de toda competência regulamentar do $\mathrm{CMN}^{\prime \prime}$ ).

\section{JURISPRUDÊNCIA DO STF}

Após a exposição da doutrina, vejamos o que diz o Supremo Tribunal Federal sobre a constitucionalidade da competência normativa do CMN.

Ainda que o STF nunca tenha enfrentado centralmente a questão em sede de ação de constitucionalidade, em diversas ocasiões a corte manifestou-se lateralmente sobre o tema, sempre decidindo que o CMN possui competência normativa. Entre 
MEINBERG, Marcio Ortiz. Sobre a competência normativa do Conselho Monetário Nacional e do Banco Central do Brasil. Revista Eletrônica Direito e Política, Programa de Pós-Graduação Stricto Sensu em Ciência Jurídica da UNIVALI, Itajaí, v.16, n.3, 30 quadrimestre de 2021. Disponível em: www.univali.br/direitoepolitica - ISSN 1980-7791.

tais decisões, podemos citar os seguintes: ADI 418, ADI 4, ADI 886 MC, ADI 1277 MC, ADI 1376 MC, ADI 1715 MC, ADI 1398 MC, ADI 2317 MC e ADI 135765.

Em todos os casos acima, o STF limitou-se apenas a reconhecer que o CMN possui competência normativa dentro de suas atribuições (eventualmente indicando a Lei no 4.595/64), mas sem avaliar se este modelo regulatório é constitucional, sem violar os princípios da legalidade e da separação dos Poderes (com exceção da ADI 1398 MC, que faz críticas superficiais, mas sem rejeitá-la), e sem referências ao artigo 25 do Ato das Disposições Constitucionais Transitórias.

Somente em 2005 localizamos a primeira decisão que faz referência e debate a questão do artigo 25 do ADCT, mas em sede de recurso extraordinário.

O tema foi debatido no RE 286.963-5 MG, a partir do voto divergente do ministro Marco Aurélio Mello. Na ocasião, Marco Aurélio retomou o histórico das medidas provisórias e leis que, em atendimento ao artigo 25 do ADCT, buscavam prorrogar a vigência da competência normativa do CMN (aponta ele, inclusive, que a MP 45 perdeu sua eficácia antes de ser reeditada pela MP 53). O ministro entendeu que:

\begin{abstract}
Admite-se que 0 artigo 25 do Ato das Disposições Constitucionais Transitórias não haja delimitado a prorrogação do prazo nele previsto - de 180 dias. Todavia, há de se dar interpretação ao texto a partir da razoabilidade. Em síntese, não se coaduna com o citado princípio a sucessividade de leis elastecendo um prazo de 180 de forma indeterminada. Hoje, passados mais de 16 anos de vigência da Carta de 1988, tem-se, ainda a competência do Conselho Monetário Nacional a partir de extravagante delegação, porquanto contrária aos ditames constitucionais. Há de se proclamar a supremacia da Carta da República, predicando que apanha não apenas os preceitos situados no corpo permanente, mas também no Ato das Disposições Transitórias. ${ }^{66}$
\end{abstract}

\footnotetext{
65 Esta seleção de casos foi realizada por DURAN, Camila Villard. O STF e a construção institucional das agências reguladoras do mercado financeiro. In: Revista Direito GV, v. 9, p. 67-94, 2009. Disponível em <https://doi.org/10.1590/S1808-24322009000100004>. Acesso em 15/07/2021. A eles ainda se somava a ADI 2591, que será abordada a seguir.

66 BRASIL. Supremo Tribunal Federal. RE 286.963-5 MG. Recurso Extraordinário no 286.963-5/MG. Acordão. Relator(a): SEPÚLVEDA PERTENCE, Primeira Turma, julgado em 24/05/2005, DJ 20/10/2006.

p.

16. 
MEINBERG, Marcio Ortiz. Sobre a competência normativa do Conselho Monetário Nacional e do Banco Central do Brasil. Revista Eletrônica Direito e Política, Programa de Pós-Graduação Stricto Sensu em Ciência Jurídica da UNIVALI, Itajaí, v.16, n.3, 30 quadrimestre de 2021. Disponível em: www.univali.br/direitoepolitica - ISSN 1980-7791.

Assim, Marco Aurélio votou pela declaração de "inconstitucionalidade da última lei que implicou a prorrogação dos 180 dias previstos no artigo 25 do Ato das Disposições Constitucionais Transitórias" ${ }^{67}$. Este entendimento foi acompanhado pelo ministro Carlos Ayres Britto, para quem "é da lógica do Ato das Disposições Constitucionais Transitórias que a Constituição passe a vigorar, no futuro, sem apêndice", funcionando "exclusivamente com sua parte permanente" 68 .

Eis que o ministro Eros Roberto Grau apresentou posição divergente. Além de argumentação parcialmente consequencialista69, Eros Grau esclarece que há distinção entre delegação de função legislativa ao Poder Executivo e atribuição de função normativa ${ }^{70}$ e, com relação ao $A D C T$, aponta que:

O que o art. 25 permite é que se exerça, enquanto não houver lei regulando a matéria, mediante ação do Poder Executivo ou órgão do Poder Executivo, a capacidade normativa de conjuntura. O limite no tempo [...] será aquele suficiente para que o Congresso Nacional crie os textos normativos que se tornem necessários para adaptar plenamente a situação do texto da Constituição. Se o Poder Legislativo levar trinta e dois anos sem editar esses textos normativos é necessário que alguém regule. ${ }^{71}$

A argumentação de Eros Grau foi acompanhada pelo relator, ministro Sepúlveda Pertence.

O ministro Cezar Peluso (que já havia acompanhado o relator) pareceu tocado pela posição de Marco Aurélio ${ }^{72}$, mas entendeu que o tema em discussão não seria apenas a revogação, pelo artigo 25 do ADCT, do poder normativo do CMN, mas também a revogação das resoluções e instruções por ele baixadas durante seu exercício. E concluiu que não teria havido a revogação das resoluções e instruções

<https://redir.stf.jus.br/paginadorpub/paginador.jsp?docTP=AC\&docID=260042>. Acesso em 24/07/2021.

67 BRASIL. Supremo Tribunal Federal. RE 286.963-5 MG. p. 17.

68 BRASIL. Supremo Tribunal Federal. RE 286.963-5 MG. p. 20.

69 BRASIL. Supremo Tribunal Federal. RE 286.963-5 MG. p. 29.

70 BRASIL. Supremo Tribunal Federal. RE 286.963-5 MG. p. 23-24.

71 BRASIL. Supremo Tribunal Federal. RE 286.963-5 MG. p. 25.

72 BRASIL. Supremo Tribunal Federal. RE 286.963-5 MG. p. 36. 
MEINBERG, Marcio Ortiz. Sobre a competência normativa do Conselho Monetário Nacional e do Banco Central do Brasil. Revista Eletrônica Direito e Política, Programa de Pós-Graduação Stricto Sensu em Ciência Jurídica da UNIVALI, Itajaí, v.16, n.3, 30 quadrimestre de 2021. Disponível em: www.univali.br/direitoepolitica - ISSN 1980-7791.

do CMN, e assim acompanhou o relator Sepúlveda Pertence, juntamente com Eros Grau, sendo esta a posição vencedora:

EMENTA: Conselho Monetário Nacional: competência para dispor sobre a taxa de juros bancários: ADCT/88, art. 25: L. 4.595/64: não revogação. 1.Validade da aplicação ao caso, da L. 4.595/64, na parte em que outorga poderes ao Conselho Monetário Nacional para dispor sobre as taxas de juros bancários, uma vez que editada dentro do prazo de 180 dias estipulado pelo dispositivo transitório, quando o Poder Executivo possuía competência para dispor sobre instituições financeiras e suas operações: indiferente, para a sua observância, que tenha havido ou não a prorrogação admitida no art. 25 do ADCT; portanto, não há falar em revogação da Lei 4.595/64. 2.RE provido, para determinar que o Tribunal a quo reaprecie a demanda tendo em conta o disposto na $L$. 4.595/64. (RE 286963, Relator(a): SEPÚLVEDA PERTENCE, Primeira Turma, julgado em 24/05/2005, DJ 20-10-2006 PP00063 EMENT VOL-02252-03 PP-00563 LEXSTF v. 28, $\mathrm{n}$. 336,2006 , p. 190-214). ${ }^{73}$ (grifo nosso)

Posteriormente, em 2006, o tema foi retomado na ADI 2591, na qual o voto do ministro Eros Grau retoma o argumento da capacidade normativa de conjuntura. Esta tese foi vencedora por maioria e incorporada à ementa:

EMENTA: [...] CONSELHO MONETÁRIO NACIONAL. ART. 40, VIII, DA LEI N. 4.595/64. CAPACIDADE NORMATIVA ATINENTE À CONSTITUIÇÃO, FUNCIONAMENTO E FISCALIZAÇÃO DAS INSTITUIÇÕES FINANCEIRAS. ILEGALIDADE DE RESOLUÇÕES QUE EXCEDEM ESSA MATÉRIA. 9. O Conselho Monetário Nacional é titular de capacidade normativa --- a chamada capacidade normativa de conjuntura --- no exercício da qual lhe incumbe regular, além da constituição e fiscalização, o funcionamento das instituições financeiras, isto é, o desempenho de suas atividades no plano do sistema financeiro. 10 . Tudo o quanto exceda esse desempenho não pode ser objeto de regulação por ato normativo produzido pelo Conselho Monetário Nacional. 11. A produção de atos normativos pelo Conselho Monetário Nacional, quando não respeitem ao funcionamento das instituições financeiras, é abusiva, consubstanciando afronta à legalidade. [...] (ADI

\footnotetext{
73 BRASIL. Supremo Tribunal Federal. RE 286.963-5 MG. p. 1.
} 
MEINBERG, Marcio Ortiz. Sobre a competência normativa do Conselho Monetário Nacional e do Banco Central do Brasil. Revista Eletrônica Direito e Política, Programa de Pós-Graduação Stricto Sensu em Ciência Jurídica da UNIVALI, Itajaí, v.16, n.3, 30 quadrimestre de 2021. Disponível em: www.univali.br/direitoepolitica - ISSN 1980-7791.

2591, Relator(a): CARLOS VELLOSO, Relator(a) p/ Acórdão: EROS GRAU, Tribunal Pleno, julgado em 07/06/2006, DJ 2909-2006 PP-00031 EMENT VOL-02249-02 PP-00142 RTJ VOL00199-02 PP-00481) ${ }^{74}$ (grifo nosso)

A partir de então, as decisões posteriores do STF sempre reconheceram a competência normativa do CMN, ora fazendo referência ao artigo 25 do ADCT ${ }^{75}$, ora à capacidade normativa de conjuntura ${ }^{76}$ (mas, em ambos os casos, sem desenvolver ou aprofundar a argumentação).

\section{ASPECTOS POLÊMICOS}

Ainda que o Supremo Tribunal Federal aparentemente considere o assunto pacificado, em nosso entendimento ainda existem aspectos não foram satisfatoriamente debatidos sobre a constitucionalidade da competência normativa do Conselho Monetário Nacional e do Banco Central do Brasil.

Entre tais aspectos, podemos citar os seguintes:

a) Fundamentos constitucionais da competência normativa: o STF não é claro se a competência normativa do CMN é um resquício da ordem constitucional anterior (fundamentada no artigo 25 do ADCT) ou se tratase da "capacidade normativa de conjuntura" (fundamentada no corpo permanente da Constituição Federal de 1988);

b) Aspectos formais e materiais quanto à prorrogação: o STF nunca se manifestou categoricamente sobre problemas quanto aos prazos de

\footnotetext{
74 BRASIL. Supremo Tribunal Federal. ADI 2591. p. 2.

75 A pesquisa na página de internet do STF, realizada em 24/07/2021, buscando pelo ADCT, art. 25, e pela Lei no 4.595/64 identificamos oito acórdãos a partir de 2005: RE 286963, RE 464152 AgR, AI 706938 AgR, RE 395171 AgR, RE 592905, RE 547245, AI 844474 RG e RE 1237758 AgR (antes de 2005, já havia cinco acórdãos neste sentido: RE 298438 AgR, RE 269958, RE 255373 AgR, RE 345355 e RE 255766 ED) e uma enorme quantidade de decisões monocráticas que não foram analisadas individualmente pelo autor.

${ }^{76}$ A pesquisa na página de internet do STF), realizada em 24/07/2021, buscando pela palavra-chave "capacidade normativa de conjuntura", identificou dois acórdãos (RE 570.680 e o RE 902.261) e 39 decisões monocráticas.
} 
MEINBERG, Marcio Ortiz. Sobre a competência normativa do Conselho Monetário Nacional e do Banco Central do Brasil. Revista Eletrônica Direito e Política, Programa de Pós-Graduação Stricto Sensu em Ciência Jurídica da UNIVALI, Itajaí, v.16, n.3, $3^{\circ}$ quadrimestre de 2021. Disponível em: www.univali.br/direitoepolitica - ISSN 1980-7791.

prorrogação da competência normativa via artigo 25 do ADCT, que podem ser questionados formal e materialmente; e

c) Conteúdo da(s) lei(s) complementar(es) prevista(s) no artigo 192, da Constituição: a partir da redação atual do artigo 192, CF, é possível interpretar que o prazo de vigência da competência normativa do CMN já foi cumprido, especialmente com a aprovação da Lei Complementar no 179/21 (LC 179).

\subsection{Fundamento da competência normativa}

O primeiro ponto polêmico refere-se ao aspecto material da competência normativa: se ela é um resquício da ordem constitucional anterior (mantida em vigor pelo artigo 25 do ADCT) ou se ela é fundamentada na própria ordem constitucional instituída pela Constituição Federal de 1988.

A primeira posição (defendida por Geraldo Ataliba e de Celso Antônio Bandeira de Mello) parte do entendimento de que, modelo constitucional adotado pela Constituição Federal de 1988, não há lugar para a competência normativa de órgãos do Poder Executivo, pois isso configuraria uma violação do princípio da legalidade e da separação dos Poderes. Eventualmente, a competência normativa do CMN (e apenas dele), fundada originalmente na Lei no 4.595/64, eventualmente poderia ter sido prorrogada com fundamento do artigo 25 do ADCT.

A segunda posição (defendida por Eros Grau, Eduardo Salomão Neto e Nelson Abrão) pressupõe que todos os Poderes do Estado possuem competência normativa (que não se confunde com a função legislativa, exclusiva do Poder Legislativo). Sendo assim, havendo autorização legal (no caso, a Lei no 4.595/64), o CMN pode exercer a "a capacidade normativa de conjuntura" dentro das matérias específicas. Deste modo, as medidas provisórias e leis que prorrogaram a competência normativa do CMN com fundamento no artigo 25 do ADCT seriam completamente desnecessárias.

As posições do STF quanto a isso não são totalmente claras, parte das decisões se referem diretamente a prorrogação via artigo 25 do ADCT, enquanto outras citam 
MEINBERG, Marcio Ortiz. Sobre a competência normativa do Conselho Monetário Nacional e do Banco Central do Brasil. Revista Eletrônica Direito e Política, Programa de Pós-Graduação Stricto Sensu em Ciência Jurídica da UNIVALI, Itajaí, v.16, n.3, $3^{\circ}$ quadrimestre de 2021. Disponível em: www.univali.br/direitoepolitica - ISSN 1980-7791.

a "capacidade normativa de conjuntura". Seria fundamental que este tema fosse enfrentado pelo STF, pois, caso prevaleça o entendimento da prorrogação via artigo 25 do ADCT, existem aspectos formais não solucionados (item 6.2 abaixo); e, caso prevaleça o entendimento da "capacidade normativa de conjuntura", tal modelo teria legitimidade para ser reproduzido ainda hoje (por exemplo, atribuindo competência normativa a agências reguladoras).

De nossa parte, acompanhamos a primeira posição (de Ataliba e Bandeira de Mello), que é a única compatível com o modelo da separação dos Poderes no presidencialismo e com o princípio da legalidade (sendo que a lei deve definir materialmente as obrigações impostas aos cidadãos, e não "redistribuir" competências sem expressa previsão Constituição). Por fim, o artigo 25 do ADCT reforça claramente este entendimento, pois não seria necessário estabelecer uma regra de transição, caso a "ação normativa" pudesse ser permanente.

\subsection{Aspectos formais e materiais quanto à prorrogação}

O segundo aspecto polêmico desdobra-se do entendimento de que a competência normativa é um resquício da ordem constitucional anterior, prorrogado pelas medidas provisórias e leis que mantiveram em vigor aspectos da Lei no 4.595/64, com fundamento no artigo 25 do Ato das Disposições Constitucionais Transitórias.

Em primeiro lugar, pode-se questionar se tal prorrogação poderia ter sido realizada por medida provisória ou se dependeria exclusivamente de lei formal (posição de Ataliba ${ }^{77}$ ). É possível argumentar que, por tratar-se de uma função primordial do Poder Legislativo, somente ele poderia decidir pelo tema, mediante lei formal. Outro argumento neste mesmo ponto de vista é o fato de que a MP 45 não foi convertida em lei, ou seja, não foi acatada pelo Congresso Nacional (diferente das MPs 53, 100, 188 e 277, que foram convertidas em lei pelo Congresso). Estas questões não foram tratadas pelo STF com este foco específico (da prorrogação da

\footnotetext{
77 ATALIBA, Geraldo. Delegação Normativa (Limites às Competências do C.M.N. e BACEN). p. 297.
} 
MEINBERG, Marcio Ortiz. Sobre a competência normativa do Conselho Monetário Nacional e do Banco Central do Brasil. Revista Eletrônica Direito e Política, Programa de Pós-Graduação Stricto Sensu em Ciência Jurídica da UNIVALI, Itajaí, v.16, n.3, 30 quadrimestre de 2021. Disponível em: www.univali.br/direitoepolitica - ISSN 1980-7791.

competência normativa), mas há entendimento bastante consolidado de que as limitações às medidas provisórias estão previstas expressamente no texto constitucional (CF88, art. 62, $\S 1^{\circ}$ ) e que poderiam ser reeditadas (a Emenda Constitucional no 32/01 formalizou e regulamentou expressamente esta hipótese). Logo concluímos que a prorrogação da competência normativa via medida provisória possui lastro constitucional.

Outro forte questionamento que não foi satisfatoriamente sanado pelo STF (ainda que tenha sido apontado pelo ministro Marco Aurelio Mello no RE 286.96378) é de natureza formal. A MP 53 foi editada cinco dias após a MP 45 ter expirado ${ }^{79}$ e a Lei no 8.201/91 foi publicada um dia após se extinguir o prazo da lei anterior. Quanto a isso, a única posição coerente é a de $A$ taliba ${ }^{80}$ ), pois não há como prorrogar a vigência de normas que já não mais integram o sistema. À vista disso, caso no futuro o STF venha a enfrentar o tema, provavelmente será necessária a modulação de efeitos da decisão, para não estabelecer o caos que decorreria da declaração de inconstitucionalidade de todas as normas emitidas pelo CMN e pelo BCB desde então.

Por fim, uma última questão é relacionada ao prazo de prorrogação da vigência da competência normativa. Geraldo Ataliba ${ }^{81}$ propôs uma posição bastante rígida, pela qual toda prorrogação teria que ter prazo determinado e estabelecida antes de 5/04/1989 (não seria possível nova prorrogação a partir de tal data). Por sua vez, o ministro Eros Grau defendeu que a prorrogação pode ser por prazo indeterminado, cabendo ao Congresso Nacional fazer tal juízo ${ }^{82}$. Em particular, acompanhamos o entendimento de Bandeira de Mello ${ }^{83}$ e do ministro Ayres Britto ${ }^{84}$ para quem a prorrogação não pode ocorrer indefinidamente (sem prazo), sendo

\footnotetext{
78 BRASIL. Supremo Tribunal Federal. RE 286.963-5 MG. p. 15.

79 Antes da Emenda Constitucional no 32/01, as medidas provisórias perdiam eficácia (desde a edição) se não fossem convertidas em lei no prazo de 30 dias (antiga redação da CF88, art. 62, parágrafo único).

80 ATALIBA, Geraldo. Delegação Normativa (Limites às Competências do C.M.N. e BACEN). p. 295.

81 ATALIBA, Geraldo. Delegação Normativa (Limites às Competências do C.M.N. e BACEN). p. 297.

82 BRASIL. Supremo Tribunal Federal. RE 286.963-5 MG. p. 25.

83 MELLO, Celso Antonio Bandeira de. apud ATALIBA, Geraldo. Delegação Normativa (Limites às Competências do C.M.N. e BACEN). p. 296-297.

84 BRASIL. Supremo Tribunal Federal. RE 286.963-5 MG. p. 20.
} 
MEINBERG, Marcio Ortiz. Sobre a competência normativa do Conselho Monetário Nacional e do Banco Central do Brasil. Revista Eletrônica Direito e Política, Programa de Pós-Graduação Stricto Sensu em Ciência Jurídica da UNIVALI, Itajaí, v.16, n.3, $3^{\circ}$ quadrimestre de 2021. Disponível em: www.univali.br/direitoepolitica - ISSN 1980-7791.

que o período de manutenção de tal condição transitória ultrapassou muito o razoável e hoje configura clara violação aos preceitos constitucionais, cabendo ação direta de inconstitucionalidade por omissão (ao Congresso Nacional caberia, ou aprovar a lei complementar prevista no artigo 192 da Constituição, ou revogar os dispositivos que prorrogaram a competência normativa do CMN).

\subsection{Lei(s) complementar(es) prevista(s) na CF, art. 192}

O terceiro aspecto polêmico, e o mais atual, está relacionado ao possível decurso do prazo de prorrogação da competência normativa do CMN, com fundamento do artigo 25 do ADCT, por conta da promulgação da Lei Complementar n 179/21.

Como podemos recordar, prevê a Lei no 8.392/91 que a competência normativa do CMN estaria prorrogada "até a data da promulgação da lei complementar de que trata o art. 192 da Constituição Federal". Ocorre que em 2003 (20 anos após a Lei no 8.392/91), a redação do artigo 192 da Constituição foi emendado para explicitar que o Sistema Financeiro Nacional pode ser regulamentado por mais de uma lei complementar (entre outras alterações).

Então, considerando que diversas leis complementares poderão ser aprovadas para atender aos reclames do artigo 192, da Constituição, trazemos a seguinte reflexão: qual lei complementar será utilizada como termo final do prazo indicado na Lei no 8.392/91?

Podemos sugerir alguns critérios:

a) A lei complementar que revogar a Lei no 4.595/64;

b) A lei complementar que regulamentar integralmente a estruturação do Sistema Financeiro Nacional, contendo todos os ditames expressos no artigo 192, da Constituição Federal;

c) A lei complementar que regulamentar o Conselho Monetário Nacional; ou 
MEINBERG, Marcio Ortiz. Sobre a competência normativa do Conselho Monetário Nacional e do Banco Central do Brasil. Revista Eletrônica Direito e Política, Programa de Pós-Graduação Stricto Sensu em Ciência Jurídica da UNIVALI, Itajaí, v.16, n.3, $3^{\circ}$ quadrimestre de 2021. Disponível em: www.univali.br/direitoepolitica - ISSN 1980-7791.

d) A lei complementar que regulamentar os órgãos supervisores do Sistema Financeiro Nacional.

Enfrentemos individualmente cada um deles.

\subsubsection{Critério: revogação da Lei no 4.595/64}

Não merece prosperar o critério pelo qual a competência normativa do CMN permaneceria em vigor até a aprovação de lei complementar que revogue expressamente a Lei no 4.595/64.

Ainda que a Lei no 4.595/64 tenha sido recebida como a lei complementar que atualmente regulamenta o SFN, há claro entendimento claro do STF (na ADI 449) de que tal recepção não ocorreu da lei como um todo, mas apenas naquilo que atender ao artigo 192, da Constituição. Dessarte, não há como condicionar a permanência da competência normativa do CMN a partir de aspectos formais da Lei no 4.595/64, mas somente a partir da matéria diretamente relacionada.

Concluindo, a mera revogação tácita (por regular a mesma matéria) de determinados dispositivos da Lei no 4.595/64 (independente de revogação formal) já é suficiente como critério de termo final de sua prorrogação. Restaria, de tal sorte, identificar quais são as matérias cuja regulamentação implicaria no termo final do prazo indicado na Lei no 8.392/91 (o que iremos identificar ao examinar os demais critérios).

\subsubsection{Critério: estruturação integral do SFN}

Também entendemos por insubsistente o critério pelo qual a competência normativa do CMN permaneceria em vigor até a aprovação de lei complementar que regulamente integralmente a estruturação do SFN (contendo todos os ditames expressos no artigo 192, da Constituição Federal). 
MEINBERG, Marcio Ortiz. Sobre a competência normativa do Conselho Monetário Nacional e do Banco Central do Brasil. Revista Eletrônica Direito e Política, Programa de Pós-Graduação Stricto Sensu em Ciência Jurídica da UNIVALI, Itajaí, v.16, n.3, 30 quadrimestre de 2021. Disponível em: www.univali.br/direitoepolitica - ISSN 1980-7791.

Como já exposto, a redação do artigo 192 da Constituição sofreu alteração para explicitar que não há necessidade de única lei complementar para regulamentar o Sistema Financeiro Nacional (posição que já era defendida até mesmo antes da Emenda Constitucional no 40/03 por alguns doutrinadores, como Virgílio Afonso da Silva e Jean Paul Cabral Veiga da Rocha ${ }^{85}$ ).

A alteração da redação do artigo 192 da Constituição, por si só, já poderia servir como termo final do prazo indicado na Lei no 8.392/91. Uma vez que a atual redação do artigo estabelece uma pluralidade de leis complementares (mas não institui um limite numérico), então são infinitas as possibilidades de leis complementares regulando o Sistema Financeiro Nacional em seus incontáveis aspectos. Oras, se não é mais possível identificar quando a regulamentação estará completa, então perdeu-se o sentido originalmente previsto na Lei no 8.392/91 (de modo que este critério não se sustenta logicamente).

Poderia contra-argumentar-se que, ainda que a regulamentação absoluta do SFN seja infinita, o artigo 192 da Constituição estabelece um conjunto mínimo de temas que, uma vez regulamentados, serviriam como termo final do prazo. Restaria identificar qual é este conjunto de temas.

A antiga redação do artigo 192, da Constituição, trazia consigo uma lista de temas: no "caput" trazia o comando principal (estruturar o SFN) e os objetivo ("promover o desenvolvimento equilibrado do País" e "servir aos interesses da coletividade"), seguido pelos incisos e pelos parágrafos (pelo entendimento do STF firmado na ADI 4, o conteúdo dos parágrafos do CF, art. 192, dependeria de regulamentação pela referida lei complementar). Considerando que a EC 40/03 alterou a redação do artigo 192 da Constituição, certamente a redação antiga não pode ser utilizada como parâmetro.

85 SILVA, Virgílio Afonso da; RoCHA, Jean Paul Cabral Veiga. A Regulamentação do Sistema Financeiro Nacional: o artigo 192 e o mito da lei complementar única. In: Revista de Direito Mercantil: industrial, econômico e financeiro. no 127. São Paulo: Malheiros Editores, julho-setembro, 2012, p. 79-92. Disponível em <https://constituicao.direito.usp.br/wp-content/uploads/2002-RDM127Regulamentacao_192.pdf>. Acesso em 24/07/2021. 
MEINBERG, Marcio Ortiz. Sobre a competência normativa do Conselho Monetário Nacional e do Banco Central do Brasil. Revista Eletrônica Direito e Política, Programa de Pós-Graduação Stricto Sensu em Ciência Jurídica da UNIVALI, Itajaí, v.16, n.3, $3^{\circ}$ quadrimestre de 2021. Disponível em: www.univali.br/direitoepolitica - ISSN 1980-7791.

Por sua vez, a atual redação do artigo 192, da Constituição, além de explicitar a questão da diversidade de leis complementares, por um lado revogou os incisos e parágrafos, e por outro lado incluindo novos temas no "caput". Logo, caso se fosse utilizar a nova redação do artigo 192, além dos temas citados anteriormente (estruturar o SFN para "promover o desenvolvimento equilibrado do País" e "servir aos interesses da coletividade"), seria necessário acrescentar as cooperativas de crédito e a participação do capital estrangeiro. Ocorre que as cooperativas de crédito e a questão do capital estrangeiro não mantém qualquer relação temática com a competência normativa do $\mathrm{CMN}$, de modo que seria bastante forçoso manter esta em vigor aquele por conta daqueles temas.

Enfim, a estruturação do SFN (incluindo seus objetivos) é um tema vago, indeterminado e bastante amplo. Afinal, qual o significado de estruturação do SFN? Estabelecer a organização e funcionamento dos órgãos supervisores do SFN? Definir e tipificar as instituições financeiras? Regulamentar aspectos monetários, bancários e creditícios? Em suma, a lista de possibilidades também é infinita. Oras, da mesma forma que a nova redação do artigo 192, da Constituição explicitou a inexistência de um limite máximo de leis complementares (ao explicitar a pluralidade de leis), a revogação dos antigos incisos e parágrafos implica que também não há um limite mínimo de temas a serem incluídos na "estruturação do SFN". Por consequência, a completa "estruturação do SFN" é indeterminável, não podendo ser utilizada como termo final do prazo indicado na Lei no 8.392/91.

\subsubsection{Critério: regulamentação do CMN}

Outro critério poderia ser a aprovação da lei complementar que regulamente o CMN. Tal critério faria perfeito sentido, uma vez que tratar-se-ia exatamente da regulamentação, entre outros aspetos, das competências deste órgão. O CMN foi criado originalmente pela própria Lei no 4.595/64 (art. 20) (em substituição ao conselho da antiga Superintendência da Moeda e do Crédito - SUMOC), que também estabeleceu os objetivos de suas políticas (Lei no 4.595/64, art. $3^{\circ}$ ), suas competências (Lei no 4.595/64, art. 4º), aspectos relacionados a natureza de suas 
MEINBERG, Marcio Ortiz. Sobre a competência normativa do Conselho Monetário Nacional e do Banco Central do Brasil. Revista Eletrônica Direito e Política, Programa de Pós-Graduação Stricto Sensu em Ciência Jurídica da UNIVALI, Itajaí, v.16, n.3, $3^{\circ}$ quadrimestre de 2021. Disponível em: www.univali.br/direitoepolitica - ISSN 1980-7791.

deliberações (Lei no 4.595/64, art. 50), composição (Lei no 4.595/64, art. 60, hoje revogado) e suas comissões (Lei no 4.595/64, art. 70, hoje revogado).

Como se vê, a estrutura original do CMN não permaneceu estanque, tendo sido inclusive objeto de alterações após a Constituição de 1988, com destaque para os seguintes:

a) A Lei no 8.392/91 alterou a composição do CMN;

b) A Lei no 9.069/95 alterou parte de suas competências, incluindo a composição do CMN; e

c) A Lei Complementar no 179/21 revogou parte das competências e dos objetivos das políticas do CMN e revogou expressamente os artigos que previam a composição do órgão e suas comissões.

Acontece que, ainda em 1995, foi proposta a ADI 1312, questionando a alteração da composição do CMN e de suas comissões por meio de lei ordinária (em particular, a Lei no 9.069/95, conversão da Medida Provisória no 542/94, diversas vezes reeditada) e não de lei complementar. Na ADI 1312 contrapuseram-se dois argumentos: o argumento de que o CMN integra o SFN, então sua organização e funcionamento dependeriam de lei complementar (CF, art. 192, IV, antiga redação); e o argumento de que o CMN não teria sido mencionado expressamente no artigo 192, IV, da Constituição (antiga redação) porque sua atuação é mais ampla do que o SFN, ou seja, sua composição poderia ser alterada pela legislação ordinária.

Apesar da relevância central da questão, em 1995 o STF entendeu que não caberia medida cautelar. Em 2004, o relator julgou prejudicada a ADI 1312, uma vez que houve alteração na redação do artigo 192 da Constituição (não houve recurso). Desta forma, o tema não foi propriamente enfrentado pelo STF, mas é fato que, 
MEINBERG, Marcio Ortiz. Sobre a competência normativa do Conselho Monetário Nacional e do Banco Central do Brasil. Revista Eletrônica Direito e Política, Programa de Pós-Graduação Stricto Sensu em Ciência Jurídica da UNIVALI, Itajaí, v.16, n.3, $3^{\circ}$ quadrimestre de 2021. Disponível em: www.univali.br/direitoepolitica - ISSN 1980-7791.

desde a década de 1990, a composição e a competência do CMN foram diversas vezes alteradas por meio da legislação ordinária (inclusive medidas provisórias) ${ }^{86}$.

Este entendimento também poderia ser fundamentado com base na atual redação do artigo 84, VI, "a" da Constituição (a partir da Emenda Constitucional no 32/01), pelo qual o Presidente da República pode "dispor, mediante decreto, sobre a organização e funcionamento da administração federal, quando não implicar em aumento das despesas e nem criação ou extinção de órgãos públicos" (que se aplica apenas a órgãos criados por lei ordinária).

Enfim, ainda que válido o entendimento de que a composição e o funcionamento do CMN seriam matéria para lei complementar, a omissão do STF ao deixar julgar o tema e prática política parecem apontar no sentido de que a legislação ordinária seria suficiente. Como resultado, para fins de identificação do termo final do prazo indicado na Lei no 8.392/91, o critério aprovação da lei complementar que regulamente o CMN parece não ser totalmente adequado.

\subsubsection{Critério: regulamentação dos órgãos supervisores do SFN}

Por fim, resta o critério final, ou seja, a aprovação da lei complementar que regulamente os órgãos supervisores do SFN.

Conforme vimos anteriormente, a partir da nova redação do artigo 192, da Constituição, não existe mais um conteúdo mínimo sobre o que seria o SFN estruturado, exceto com relação a alguns parâmetros genéricos, como seus objetivos ("promover o desenvolvimento equilibrado do País" e "servir aos interesses da coletividade") e a previsão de que as cooperativas de crédito o compõem e que cabe regulação sobre "a participação do capital estrangeiro nas instituições que o integram". Outros aspectos podem ser deduzidos a partir de da

86 Além da Lei no 8.392/91 e das reedições da MP 542 (convertida na Lei no 9.069/95), também localizamos a MP 2.216-37/01, a MP 870/19 e a Lei no $13.844 / 19$. 
MEINBERG, Marcio Ortiz. Sobre a competência normativa do Conselho Monetário Nacional e do Banco Central do Brasil. Revista Eletrônica Direito e Política, Programa de Pós-Graduação Stricto Sensu em Ciência Jurídica da UNIVALI, Itajaí, v.16, n.3, $3^{\circ}$ quadrimestre de 2021. Disponível em: www.univali.br/direitoepolitica - ISSN 1980-7791.

própria Constituição, como, por exemplo, a existência do Banco Central do Brasil (CF, art. 52, II, "b", art. 84, XIV, art. 164, e ADCT, art. 47, §60, art. 97, § 90, I).

Sendo assim, o constituinte concedeu ampla liberdade para que o legislador complementar determinasse a estrutura do SFN, inclusive quanto aos órgãos supervisores (desde que, respeitadas as demais disposições constitucionais sobre o BCB). Isso posto, o legislador complementar pode, livremente, optar por manter o formato estabelecido em 1964 (no qual havia apenas o CMN e o BCB), pode retornar ao modelo de 1945 (no qual havia um único órgão, a SUMOC), pode utilizar um conceito mais restrito de SFN, mantendo parte dos órgãos atualmente existentes (CMN, BCB e CVM), pode utilizar um conceito amplo de SFN, incluindo também neste a estrutura o mercado de seguros (ou seja, além do CMN, do BCB e da CVM, poderia incluir também o CNSP e a SUSEP) ${ }^{87}$, entre outros inúmeros formatos (por exemplo, regulando também o Conselho de Recursos do Sistema Financeiro Nacional - CRSFN ou o Conselho de Controle de Atividades Financeiras - COAF/UIF). Portanto, não há nada na Constituição que torne obrigatória a manutenção do CMN.

Em vista do que foi demonstrado, é bastante coerente o critério pelo qual a aprovação da lei complementar que regulamente os órgãos supervisores do SFN serve como termo final para o prazo estabelecido na Lei no 8.392/91. Tal lei complementar poderia reformular o sistema de supervisão (respeitando ao menos as disposições constitucionais sobre o BCB), como também poderia manter a existente, sendo que, neste caso, a manutenção do formato atual passa a ser interpretado sempre a partir da Constituição de 1988 (que não admite competência normativa exercida por órgãos do Poder Executivo). Tal lei complementar poderia extinguir o CMN (ou seja, deixaria de existir o órgão a quem a competência normativa havia sido atribuída em 1964) ou poderia manter o CMN, mas sem resquícios da ordem constitucional anterior (cumprindo o desígnio do Ato das Disposições Constitucionais Transitórias). Este critério também é compatível

\footnotetext{
87 A princípio, o mercado de previdência complementar também caberia em um conceito mais amplo de SFN, porém a atual redação do artigo 202, da Constituição, prevê a existência de uma lei complementar específica para a previdência privada.
} 
MEINBERG, Marcio Ortiz. Sobre a competência normativa do Conselho Monetário Nacional e do Banco Central do Brasil. Revista Eletrônica Direito e Política, Programa de Pós-Graduação Stricto Sensu em Ciência Jurídica da UNIVALI, Itajaí, v.16, n.3, $3^{\circ}$ quadrimestre de 2021. Disponível em: www.univali.br/direitoepolitica - ISSN 1980-7791.

com o entendimento de que o $\mathrm{CMN}$ não precisa ser regulamentado por lei complementar, de modo que a regulamentação por lei complementar ficaria restrita ao Banco Central do Brasil e eventuais outros órgãos supervisores que ela viesse a criar.

Concluído sinteticamente, em nosso entendimento o prazo indicado na Lei no 8.392/91 será atingido com a aprovação da lei complementar que regulamentar os órgãos supervisores do SFN (independentemente da regulamentação específica do CMN). O critério da "revogação expressa da Lei no 4.595/64" é meramente formal e inadequado, pois existem aspectos da referida lei que foram recebidos apenas como lei ordinária. O critério da "lei complementar que regulamente integralmente o SFN" não se sustenta já que, após a alteração do artigo 192 da Constituição, seria impossível de determinar o termo final do prazo. Por fim, critério da "lei complementar que regulamentar o CMN" somente subsistiria se houvesse entendimento do STF de que se trata de matéria a ser regulada por lei complementar (o que contraria a constante prática de alterações de sua composição por medidas provisórias e leis ordinárias, praticada desde 1991).

\subsubsection{Lei Complementar no 179/21}

Enfim, com isso chegamos à Lei Complementar no 179/21, que "define os objetivos do Banco Central do Brasil e dispõe sobre sua autonomia e sobre a nomeação e a exoneração de seu Presidente e de seus Diretores; e altera artigo da Lei no 4.595, de 31 de dezembro de 1964". Como se vê, a LC 179 trata da organização, funcionamento e atribuições do $\mathrm{BCB}$ e, além de fazer referências diretas ao $\mathrm{CMN}$ e promove diversas alterações na Lei no 4.595/64 relacionadas ao BCB e ao CMN.

Oras, trata-se de lei complementar que, apesar do enfoque no BCB, está regulamentando os órgãos supervisores do SFN, inclusive o CMN (parcialmente). Então, a estrutura proposta mantém os existentes CMN e BCB como órgãos supervisores do SFN. Sem embargo, a exclusão, pela LC 179/21 do artigo $6^{\circ}$ da Lei no 4.595/64 (que estabelecia a composição do CMN) demonstra claramente que o CMN deverá ser regulamentado pela legislação ordinária e não por lei 
MEINBERG, Marcio Ortiz. Sobre a competência normativa do Conselho Monetário Nacional e do Banco Central do Brasil. Revista Eletrônica Direito e Política, Programa de Pós-Graduação Stricto Sensu em Ciência Jurídica da UNIVALI, Itajaí, v.16, n.3, $3^{\circ}$ quadrimestre de 2021. Disponível em: www.univali.br/direitoepolitica - ISSN 1980-7791.

complementar. Assim sendo, as disposições da Lei no 4.595/64 referentes ao CMN que ali restaram devem ser interpretadas com status de lei ordinária.

Diante disso, não resta outra alternativa senão considerar que a Lei Complementar no 179/21 é a lei complementar que serve como termo final do prazo estabelecido na Lei no 8.392/91. Desta maneira, uma vez feita a regulamentação dos órgãos supervisores do SFN, estes perdem quaisquer resquícios da ordem constitucional anterior que tinham sido mantidos por força do artigo 25 do Ato das Disposições Constitucionais Transitórias.

\section{CONSIDERAÇÕES FINAIS}

Resumindo o artigo de forma bastante apressada, concluímos que a discussão sobre a competência normativa do Conselho Monetário Nacional (apenas ele, uma vez que o Banco Central do Brasil nunca a possuiu), apesar de antiga, ainda não foi satisfatoriamente superada. Grandes doutrinadores divergem sobre o tema, enquanto o Supremo Tribunal Federal nunca abordou a questão de forma a debater todas as nuances.

Além disso, existem ao menos três temas polêmicos que ainda precisam ser discutidos, pois causam enormes repercussões sobre a forma como se concebe a ordem econômica e o Sistema Financeiro Nacional: quanto ao fundamento de tal competência; quanto a aspectos formais e materiais relacionados à prorrogação via artigo 25 do ADCT; e quanto ao conteúdo da lei complementar prevista no artigo 192 da Constituição Federal (que seria o termo final da prorrogação fundada no ADCT, art. 25).

Em nosso entendimento, a competência normativa do CMN é um resquício da ordem constitucional anterior e incompatível com o princípio da legalidade e da separação dos Poderes. Contudo, seu fundamento está em dispositivos da Lei no 4.595/64, mantidos em vigor por medidas provisórias e leis aprovadas com base no artigo 25 do Ato das Disposições Constitucionais Transitórias (em especial, a Lei no 8.392/91, art. $\left.1^{0}\right)$. Como é próprio das disposições transitórias, que não 
MEINBERG, Marcio Ortiz. Sobre a competência normativa do Conselho Monetário Nacional e do Banco Central do Brasil. Revista Eletrônica Direito e Política, Programa de Pós-Graduação Stricto Sensu em Ciência Jurídica da UNIVALI, Itajaí, v.16, n.3, $3^{\circ}$ quadrimestre de 2021. Disponível em: www.univali.br/direitoepolitica - ISSN 1980-7791.

podem ser permanentes, é inconstitucional o prazo indeterminado de prorrogação da competência normativa do CMN. Da mesma forma, o decurso de três décadas implica em grave omissão por parte do Congresso Nacional, que possui o dever constitucional de revogar tal competência. Por fim, a aprovação da Lei Complementar no 179/21, que regulamenta o BCB deve ser interpretada como o evento de termo final de tal prorrogação, pois estrutura os órgãos supervisores do Sistema Financeiro Nacional (uma vez que a regulamentação do CMN não depende de lei complementar).

\section{REFERÊNCIAS DAS FONTES CITADAS}

ABRÃO, Nelson. Direito Bancário. 18 a ed. São Paulo: Saraiva Educação, 2019.

ARAÚJO, Luiz Alberto David; NUNES JÚNIOR, Vidal Serrano. Curso de Direito Constitucional. 22a ed. rev. e atual. São Paulo: Verbatim, 2018.

ATALIBA, Geraldo. Delegação Normativa (Limites às Competências do C.M.N. e BACEN). In: Revista de Informação Legislativa, Brasília, a. 29, n. 113, p. 275306, jan/mar, 1992. Disponível em <https://www2.senado.leg.br/bdsf/bitstream/handle/id/175926/000459246.pdf? sequence $=1$ \&isAllowed $=y>$. Acesso em 24/07/2021.

BRASIL. Supremo Tribunal Federal. ADI 2591. Ação Direta de Inconstitucionalidade no 2.591-1/DF. Acórdão. Relator(a): CARLOS VELLOSO, Relator(a) p/ Acórdão: EROS GRAU, Tribunal Pleno, julgado em 07/06/2006, DJ 29/09/2006, p. 191 Disponível em <https://redir.stf.jus.br/paginadorpub/paginador.jsp?docTP=AC\&docID=266855 $>$. Acesso em 24/07/2021.

BRASIL. Supremo Tribunal Federal. RE 286.963-5 MG. Recurso Extraordinário no 286.963-5/MG. Acordão. Relator(a): SEPÚLVEDA PERTENCE, Primeira Turma, julgado em 24/05/2005, DJ 20/10/2006. p. 16. Disponível em <https://redir.stf.jus.br/paginadorpub/paginador.jsp?docTP=AC\&docID =260042 $>$. Acesso em 24/07/2021.

COMPARATO, Fábio Konder. Abertura de crédito - Nulidade de cláusula contratual. In: Revista de Direito Mercantil, Industrial, Econômico e Financeiro, v. 10, n. 3, 1971 , p. 59 a 62.

DURAN, Camila Villard. O STF e a construção institucional das agências reguladoras do mercado financeiro. In: Revista Direito GV, v. 9, p. 67-94, 2009. Disponível em <https://doi.org/10.1590/S1808-24322009000100004>. Acesso em 15/07/2021. 
MEINBERG, Marcio Ortiz. Sobre a competência normativa do Conselho Monetário Nacional e do Banco Central do Brasil. Revista Eletrônica Direito e Política, Programa de Pós-Graduação Stricto Sensu em Ciência Jurídica da UNIVALI, Itajaí, v.16, n.3, 30 quadrimestre de 2021. Disponível em: www.univali.br/direitoepolitica - ISSN 1980-7791.

FERrAZ, Anna Cândida da Cunha. Conflito entre Poderes. São Paulo: Editora Revista dos Tribunais, 1994.

GRAU, Eros Roberto. O Direito Posto e o Direitos Pressuposto. São Paulo: Malheiros Editores, 2002.

MELLO, Celso Antônio Bandeira de. Curso de Direito Administrativo. 26a ed. rev. e atual. São Paulo, Malheiros, 2009.

MORAES, Alexandre de. Direito Constitucional. 22a ed. São Paulo: Atlas, 2007. PESSOA, João Paulo. As Disposições Transitórias do Direito Constitucional Brasileiro. Rio de Janeiro: Lumen Juris, 2017.

SALOMÃO NETO, Eduardo. Direito Bancário. $3^{a}$ ed. rev. e ampl. São Paulo: Trevisan Editora, 2020.

SILVA, José Afonso da. Curso de Direito Constitucional. 19a ed. rev. e atual. São Paulo: Malheiros, 2001.

SILVA, Virgílio Afonso da; ROCHA, Jean Paul Cabral Veiga. A Regulamentação do Sistema Financeiro Nacional: o artigo 192 e o mito da lei complementar única. In: Revista de Direito Mercantil: industrial, econômico e financeiro. no 127. São Paulo: Malheiros Editores, julho-setembro, 2012, p. 79-92. Disponível em <https://constituicao.direito.usp.br/wp-content/uploads/2002-RDM127-

Regulamentacao_192.pdf>. Acesso em 24/07/2021. 